\title{
Trehalose protects corneal epithelial cells from death by drying
}

\author{
Toshihiko Matsuo
}

\begin{abstract}
Aim-This study was designed to examine whether trehalose could protect corneal epithelial cells in culture from death by desiccation in order to test trehalose as a potential new eye drop for dry eye syndrome.

Methods-Human corneal epithelial cells in near confluent culture in wells of a 96 well multidish were preincubated for 15 minutes with $2,20,50,100$, or $200 \mathrm{mM}$ trehalose or maltose in phosphate buffered saline (PBS), PBS alone, or three kinds of commercially available artificial tear substitutes (one with borate buffered saline and the other two containing either hydroxyethylcellulose or hyaluronan). The medium was aspirated completely and cells were left dry for $\mathbf{3 0}$ minutes at room temperature in room humidity. Live cells and dead cells were visualised by fluorescent dyes and counted for statistical analysis.

Results-The percentage of dead corneal epithelial cells after desiccation was significantly lower in preincubation with 50 , 100 , and $200 \mathrm{mM}$ trehalose, compared with preincubation with PBS alone $(\mathbf{p}<0.0001$, Kruskal-Wallis test, and $\mathrm{p}<0.05$, Tukey-Kramer test). Trehalose at the concentration of $20 \mathrm{mM}$ or lower, maltose at any concentrations, and commercially available artificial tear substitutes did not protect corneal epithelial cells from death by desiccation.

Conclusions-Trehalose at 50, 100, and $200 \mathrm{mM}$ protected corneal epithelial cells in culture from death by desiccation. Trehalose could be used as a potential new eye drop for dry eye syndrome.

(Br f Ophthalmol 2001;85:610-612)
\end{abstract}

Dry eye syndrome ${ }^{1}$ or keratoconjunctivitis sicca, including Sjögren's syndrome, ${ }^{2}$ is one of the most prevalent diseases in the eye. Dryness, caused by the imbalance of tear film on the ocular surface, coupled sometimes with eyelid problems, leads to corneal epithelial cell damage and symptoms such as pain, itching, burning, and foreign body sensation. The tear film on the ocular surface consists of three layersouter lipid layer, middle aqueous layer, and inner mucous layer. Deficiencies in one of these constituents make epithelial cells prone to be dry. Major means of the treatment for dry eye syndrome are tear substitutes such as artificial tear eye drops. Hyaluronan eye drops have been recently introduced as a tear substitute. $^{3}$
Trehalose is a disaccharide, a key element for anhydrobiosis (capability of surviving almost complete dehydration) in many organisms. ${ }^{4}$ Its presence also confers desiccation resistance to bacterial cells ${ }^{5}$ and human cells. ${ }^{6}$ In this study, trehalose was tested to see if it protected corneal epithelial cells in culture from death by desiccation.

\section{Methods}

Human corneal epithelial cells in the third passage obtained from normal eye bank eyes (Kurabo, Osaka, Japan and Cascade Biologics, Portland, OR, USA) were cultured to near confluence in wells of a 96 well polystyrene multidish (Iwaki, Tokyo, Japan) containing a serum-free medium with $5 \mu \mathrm{g} / \mathrm{ml}$ insulin, 10 $\mathrm{ng} / \mathrm{ml}$ mouse EGF, $0.18 \mu \mathrm{g} / \mathrm{ml}$ hydrocortisone, $5 \mu \mathrm{g} / \mathrm{ml}$ transferrin, $100 \mu \mathrm{g} / \mathrm{ml}$ streptomycin, 25 $\mathrm{ng} / \mathrm{ml}$ amphotericin $\mathrm{B}, 10$ units/ml penicillin, and $0.4 \% \quad(\mathrm{v} / \mathrm{v})$ bovine pituitary extracts (Kurabo-Cascade Biologics). After the medium was aspirated completely, cells in each well were incubated for 15 minutes with 2, 20, 50,100 , or $200 \mathrm{mM}$ trehalose, 2, 20, 50, 100, or $200 \mathrm{mM}$ maltose in phosphate buffered saline (PBS: $10 \mathrm{mM}$ phosphate, $138 \mathrm{mM}$ $\mathrm{NaCl}, 2.7 \mathrm{mM} \mathrm{KCl}, \mathrm{pH}$ 7.4, Sigma), PBS alone, $0.1 \%$ sodium hyaluronate eye drops (Hyalein: Santen Pharmaceuticals, Osaka, Japan), or artificial tear eye drops (Mytear: containing hydroxyethylcellulose, Senju Pharmaceuticals, Osaka, and Soft Santear: borate buffered saline, Santen Pharmaceuticals) in a volume of $200 \mu \mathrm{l}$. The medium was aspirated completely, and cells were left to dry for 30 minutes at room temperature $\left(24-25^{\circ} \mathrm{C}\right)$ in room humidity $(34-40 \%)$. Cells were then incubated for 15 minutes with SYTO 10 green fluorescent nucleic acid stain and DEAD Red nucleic acid stain (LIVE/DEAD Reduced Biohazard Viability/Cytotoxicity Kit: Molecular Probe, Eugene, OR, USA) in HEPES buffered saline (HBS: $135 \mathrm{mM} \mathrm{NaCl}, 5 \mathrm{mM} \mathrm{KCl}, 1$ $\mathrm{mM} \mathrm{MgSO}_{4}, 1.8 \mathrm{mM} \mathrm{CaCl}_{2}, 10 \mathrm{mM}$ HEPES, $\mathrm{pH} 7.4)$. After fixing with $4 \%$ glutaraldehyde in HBS, live cells and dead cells were visualised with $100 \mathrm{~W}$ mercury lamp as a light source under an inverted microscope (Zeiss Axiovert $405 \mathrm{M})$ through a set of FITC and PI filters. Photographs in the centre of each well were taken with $\times 10$ magnification by double exposure through each filter to $35 \mathrm{~mm}$ films (Fujichrome 400, Fuji) at the exposure time of 60 seconds and 30 seconds, respectively.

Three wells were assigned to each condition of preincubation in one series of experiments, and the whole procedure was repeated twice to obtain the number of six for each condition. 

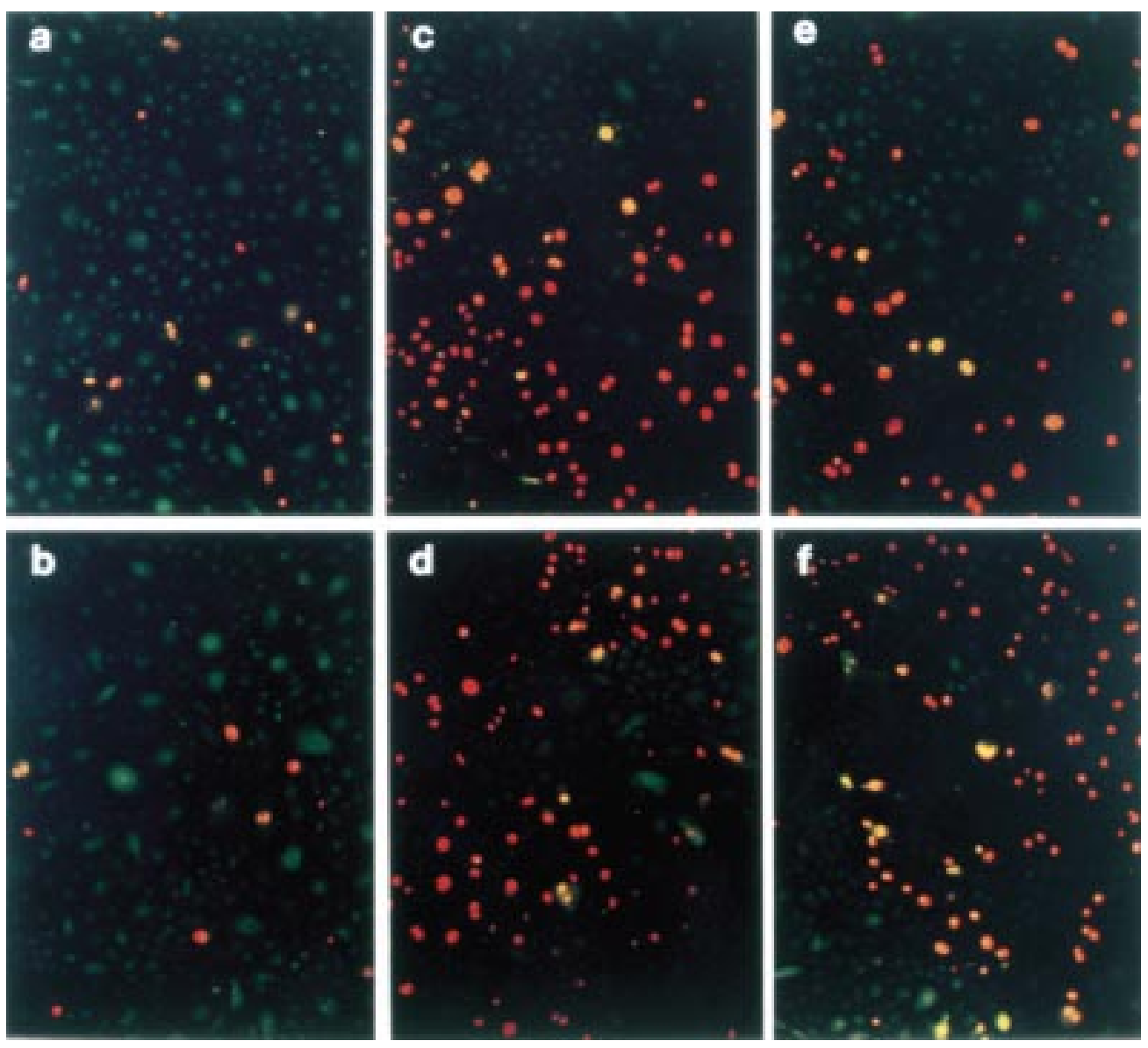

Figure 1 Live cells (green) and dead cells (orange) after 30 minute desiccation visualised by LIVE/DEAD Reduced Biohazard Viability/Cytotoxicity Kit (Molecular Probe). The number of dead cells is smaller after preincubation with 200 $\mathrm{mM}$ trehalose (a) and $100 \mathrm{mM}$ trehalose (b), compared with preincubation with $200 \mathrm{mM}$ maltose (c), $100 \mathrm{mM}$ maltose (d), $0.1 \%$ hyaluronan (e), and phosphate buffered saline $(f)$.

Green live cells (stained with SYTO 10) and orange dead cells (stained with both SYTO 10 and Dead Red) in six photographs for each condition were counted, and the percentage of dead cells in the total cells was analysed statistically (StatView 5.0, SAS Institute).

\section{Results}

The percentage of dead corneal epithelial cells after desiccation was significantly lower in the preceding incubation with 50, 100, and 200
$\mathrm{mM}$ trehalose, compared with the incubation with PBS alone $(\mathrm{p}<0.0001$, Kruskal-Wallis test, and $\mathrm{p}<0.05$, Tukey-Kramer test, Fig 1 and Table 1). The total number of cells in near confluency varied from well to well because human corneal epithelial cells in culture varied markedly in size (Fig 1).

Corneal epithelial cells could not be rescued from death from desiccation by the preceding incubation with trehalose at the concentration of $20 \mathrm{mM}$ or lower, maltose at any concentrations,

Table 1 The number and the percentage of dead corneal epithelial cells after 30 minutes of desiccation under different preceding conditions

\begin{tabular}{|c|c|c|c|c|c|c|c|}
\hline \multicolumn{7}{|c|}{ Dead cells/total cells (\%) } & \multirow[b]{2}{*}{$\begin{array}{l}\text { Median } \\
\text { percentage }\end{array}$} \\
\hline Preincubation & Well No 1 & Well No 2 & Well No 3 & Well No 4 & Well No 5 & Well No 6 & \\
\hline PBS & $525 / 623(84.3)$ & $603 / 869(69.4)$ & $429 / 867(49.5)$ & $237 / 259(91.5)$ & $381 / 493(74.8)$ & $410 / 569(72.1)$ & 73.5 \\
\hline Mytear & $428 / 875(48.9)$ & $483 / 1085(44.5)$ & $372 / 538(69.1)$ & $310 / 363(85.4)$ & $280 / 335(83.6)$ & $300 / 447(67.1)$ & 68.1 \\
\hline Soft Santear & $353 / 735(48.0)$ & $301 / 533(56.5)$ & $450 / 547(82.3)$ & $349 / 547(63.8)$ & $226 / 336(67.3)$ & $338 / 443(76.3)$ & 65.6 \\
\hline Hyalein & $524 / 676(77.5)$ & $522 / 699(74.8)$ & $393 / 421(93.3)$ & $410 / 569(72.1)$ & $449 / 506(88.7)$ & $449 / 521(86.2)$ & 81.9 \\
\hline Maltose $200 \mathrm{mM}$ & $295 / 823(35.8)$ & $472 / 769(61.4)$ & $305 / 875(34.9)$ & $144 / 487(29.6)$ & $270 / 530(50.9)$ & $422 / 529(79.8)$ & 43.4 \\
\hline Maltose $100 \mathrm{mM}$ & $448 / 1019(44.0)$ & $475 / 861(55.7)$ & $323 / 658(49.1)$ & $196 / 237(82.7)$ & $342 / 413(82.8)$ & $352 / 572(61.5)$ & 58.6 \\
\hline Maltose $50 \mathrm{mM}$ & $304 / 594(51.2)$ & $495 / 659(75.1)$ & $356 / 537(66.3)$ & $257 / 352(73.0)$ & $286 / 314(91.1)$ & $433 / 567(76.4)$ & 74.1 \\
\hline Maltose $20 \mathrm{mM}$ & $487 / 1019(47.8)$ & $588 / 982(59.9)$ & $279 / 461(60.5)$ & $231 / 321(72.0)$ & $385 / 571(67.4)$ & $292 / 408(71.6)$ & 64.0 \\
\hline Maltose $2 \mathrm{mM}$ & $343 / 783(43.8)$ & $324 / 673(48.1)$ & $279 / 451(61.9)$ & $244 / 377(64.7)$ & $497 / 669(74.3)$ & $287 / 507(56.9)$ & 59.4 \\
\hline Trehalose $200 \mathrm{mM}$ & $37 / 1244(0.03)$ & $58 / 813(0.1)$ & $112 / 921(12.2)$ & $82 / 650(12.6)$ & $84 / 527(15.9)$ & $67 / 577(11.6)$ & 11.9 \\
\hline Trehalose $100 \mathrm{mM}$ & $263 / 1024(25.7)$ & $86 / 736(11.7)$ & $136 / 824(16.5)$ & $13 / 429(26.3)$ & $115 / 713(21.7)$ & $51 / 399(12.8)$ & 19.1 \\
\hline Trehalose $50 \mathrm{mM}$ & $205 / 959(21.4)$ & $254 / 916(27.7)$ & $415 / 1113(37.3)$ & $167 / 895(18.7)$ & $155 / 1028(15.1)$ & $120 / 729(15.2)$ & 20.1 \\
\hline Trehalose $20 \mathrm{mM}$ & $341 / 971(35.1)$ & $329 / 788(41.8)$ & $450 / 741(60.7)$ & $332 / 440(75.5)$ & $327 / 501(65.3)$ & $367 / 663(55.4)$ & 58.1 \\
\hline Trehalose $2 \mathrm{mM}$ & $473 / 964(49.1)$ & $469 / 754(62.2)$ & $498 / 690(72.2)$ & $264 / 420(62.9)$ & 308/394 (78.2) & $291 / 528(55.1)$ & 62.6 \\
\hline
\end{tabular}

The preincubation with $50 \mathrm{mM}, 100 \mathrm{mM}$, and $200 \mathrm{mM}$ trehalose leads to significantly better survival of cells, compared with trehalose at the concentration of $20 \mathrm{mM}$ or lower, maltose at any concentrations, phosphate buffered saline (PBS), and commercially available tear substitutes (Mytear, Soft Santear, and Hyalein). p<0.0001, Kruskal-Wallis test; $\mathrm{p}<0.05$, Tukey-Kramer test. 
or three kinds of commercially available artificial tear substitutes (Table 1).

\section{Discussion}

This study demonstrated that trehalose at concentrations of 50,100 , and $200 \mathrm{mM}$ prevented corneal epithelial cells from death from desiccation. This effect was unique to trehalose because another disaccharide, maltose, had no effect on rescuing corneal epithelial cells from death in the same drying condition. It should be noted that there was no pattern for the response to maltose by concentration. Furthermore, there was an apparent linear trend of the response to trehalose from a concentration of $200 \mathrm{mM}$ to below a concentration of $20 \mathrm{mM}$, although the response below $20 \mathrm{mM}$ did not reach statistical significance. These facts indicate that trehalose protects corneal epithelial cells from death from desiccation by its unique mechanism.

Trehalose stabilises lipids and proteins of the cell membrane in the condition of desiccation. ${ }^{7-9}$ The effect of trehalose in desiccation is not simply by maintaining fluid around the cells. The concentration of trehalose which protected human corneal epithelial cells from death by desiccation ranged from 50 to $200 \mathrm{mM}$. This range is comparable with 100 $\mathrm{mM}$ concentration of trehalose to allow bacteria to survive during drying. ${ }^{5}$

Large variations in the percentage of dead cells were observed among the six wells under each different condition of preincubation. The dead cells were distributed evenly between corneal epithelial cells of large and small sizes. The cells in both fully confluent and near confluent areas were equally affected by desiccation. A possible reason for this variation is that desiccation took place under the natural condition of room air. Another potential reason would be that the number of cells varied largely among the six wells because of the varying sizes of human corneal epithelial cells in culture. Despite the variation among each well, the percentage of dead cells was apparently smaller in number after the preincubation with $200 \mathrm{mM}$ trehalose.

The current goal of tear substitutes for dry eye syndrome is to simply maintain hydration of the ocular surface by supplying fluid or fluid maintaining substances such as hyaluronan and cellulose. In dry eye syndrome, corneal and conjunctival epithelial cells become dead by drying on the ocular surface, and dead cells are then detached, leading to erosion and the development of symptoms. Trehalose would present a new way of treatment for dry eye syndrome since it reduces the number of dead cells on the ocular surface even under the condition of desiccation.

In this study, tear substitutes which are commercially available at present, including hyaluronan eye drops, could not prevent corneal epithelial cells from death by desiccation. The preincubation, especially with hyaluronan, led to the formation of large crystal deposits after 30 minutes of desiccation, resulting in poor survival of corneal epithelial cells. Trehalose eye drops could be used as a better tear substitute in patients with dry eye syndrome.

1 McCarty CA, Bansal AK, Livingston PM, et al. The epidemiology of dry eye in Melbourne, Australia. Ophthalmology 1998;105:1114-19.

2 Sjogren $\mathrm{H}$, Bloch KJ. Keratoconjunctivitis sicca and the Sjogren syndrome. Surv Ophthalmol 1971;16:145-59.

3 Shimmura S, Ono M, Shinozaki $K$, et al. Sodium hyaluronate eyedrops in the treatment of dry eyes. $\mathrm{Br} \mathcal{F}$ Ophthalmol 1995;79:1007-11.

4 Crowe JH, Hoekstra FA, Crowe LM. Anhydrobiosis. Annu Rev Physiol 1992;54:579-99.

5 Leslie SB, Israeli E, Lighthart B, et al. Trehalose and sucrose protect both membranes and proteins in intact bacteria during drying. Appl Environ Microbiol 1995;61:3592-7.

6 Guo N, Puhlev I, Brown DR, et al. Trehalose expression confers desiccation tolerance on human cells. Nat Biotechnol 2000;18:168-71.

7 Crowe JH, Crowe LM, Carpenter JF, et al. Stabilization of dry phospholipid bilayers and proteins by sugars. Biochem $\mathcal{F}$ 1987;242:1-10.

8 Crowe JH, Carpenter JF, Crowe LM. The role of vitrification in anhydrobiosis. Annu Rev Physiol 1998;60: 73-103.

9 Allison SD, Chang B, Randolph TW, et al. Hydrogen bonding between sugar and protein is responsible for inhibition of dehydration induced protein unfolding. Arch Biochem Biophys 1999;365:289-98. 